Journal Of Al Azhar University Engineering Sector

Vol. 13, No. 46, January, 2018, 1-13

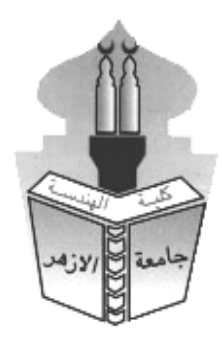

\title{
THE RELATION BETWEEN CARGO OPERATION AND WATER POLLUTION IN DAMIETTA HARBOR
}

\author{
Tamer Elgohary \\ Civil Engineering Dept., Engineering college, Heliopolis university , Cairo, Egypt

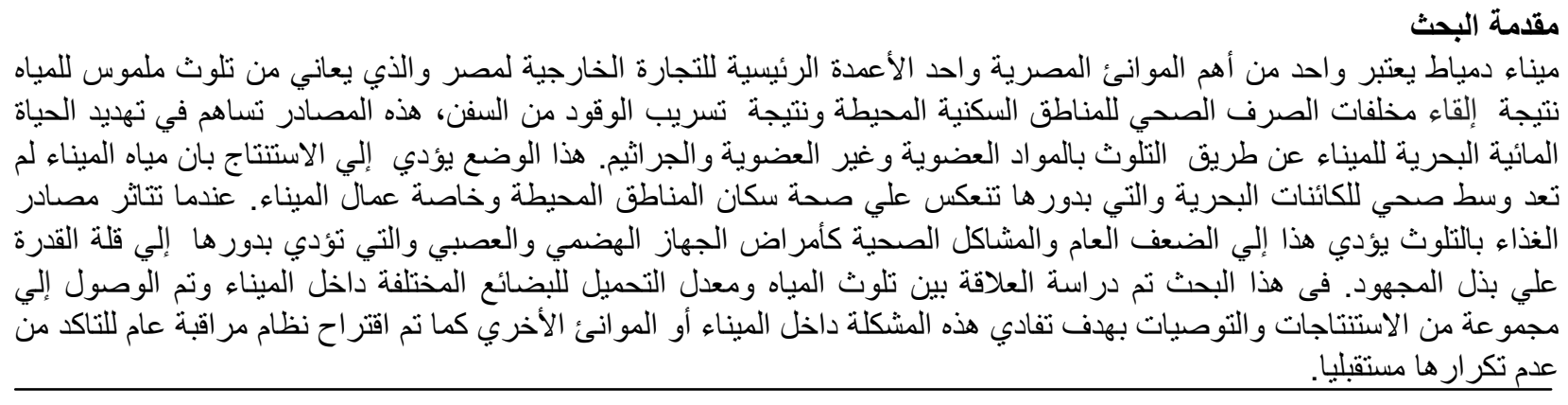

ABSTRACT

Damietta harbor as all harbor suffer from water pollution due to ship fuel leakage and surrounding urban area waste disposal in form of solid or sewage. All these point sources of pollution contribute in threatening of aquamarine life environment by adding organic or nonorganic matter pollutant and pathogens to water. This situation will lead to the fact that marine water is no longer a healthy place for aquamarine life which will be reflected in people health especially harbor labors who are feeding on such sea foods. When people health is negatively affected by such pollutant sea foods it will be appeared in form of less ability of work and long time or short time diseases. For this reasons this study was achieved in order to find the relation between pollutants different elements and cargo operation inside harbor place in form of scatters charts which will help us to more understanding of factors that effect on harbor cargo circulation. Also a Monitoring system and a group of recommendation were constructed in the end of this study in order to avoid such circumstance which affect on harbor performance and its economy.

Keywords EIA, Water pollution, ports, cargo operation, Damietta harbor.

\section{INTRODUCTION}

Sea water pollution is a major problem in our modern world due the coastal urban area enlargement and sea water economy in form of near harbors operations, fishing industrial, sea water desalination and any other related activities. All those activities will be affected negatively by sea water pollution. The negative impact factors such as outer permissible limits of dissolved oxygen (DO), total suspended solids (TSS), Total Coliform bacteria, Streptococci Bacteria, Phosphorus (po4-p), chemical oxygen demand(COD), biochemical oxygen demand (BOD) and pathogens existence in crescent.

Damietta city is one of most important cities in Egypt due to its largest share in national economy in many sectors such as petrochemicals industry, furniture industry and Damietta harbor activities. It is located at the North east of Egypt delta and the city is fed by potable water from 
Nile river branch ( Damietta branch) as shown in fig(1). Many pollutants are responsible for changing water ph such as copper, selenium, nitrites and sulfate, Also these pollutants has a negative direct effect on harbor aquatic life health that play major role in human food chain. Industrial effluent, Many sources such as near urban sewage disposal , and ships fuel leakage can contribute to form these kind of pollutants. Starting from year 1998 the Egyptian government decided to send recording campaigns each three month to take water sample in order to monitor sea water quality. Water physical and chemical properties in each place along Egyptian coast were detected such as total suspended solids (TSS), Total Coliform bacteria, Streptococci Bacteria, Phosphorus (po4-p), chemical oxygen demand(COD) and biochemical oxygen demand (BOD) [1]. Water parameter such as total suspended solids( organic and non organic particles) is responsible for water turbidity that decrease sun ray penetration and lead to the resisting of aquatic plants photosynthesis that cause finally plants death, Also suspended solids increase water temperature that lead DO to be decreased, But in other hand suspended solids could be assumed to be a good source of food to

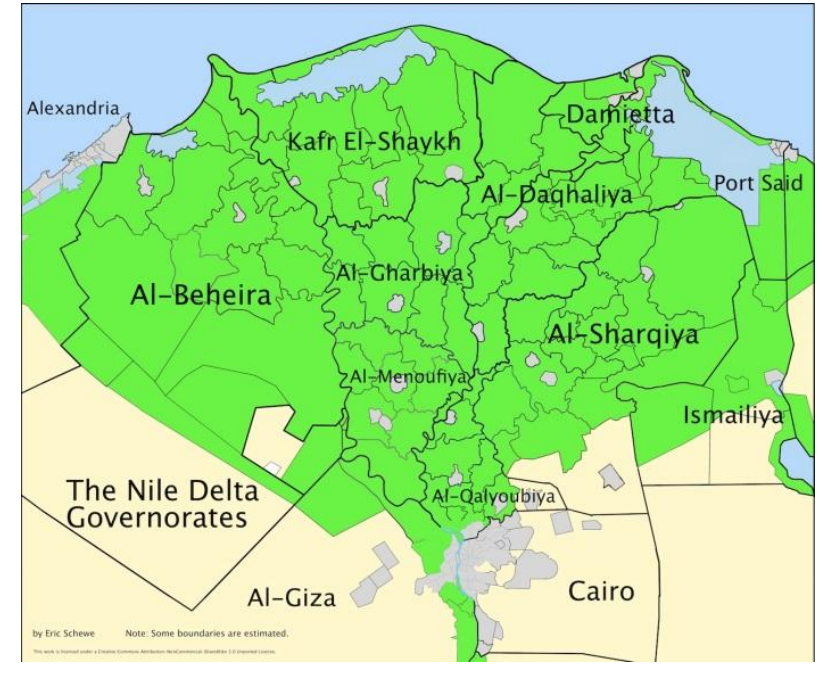

Fig(1) Egypt Delta map

aquatic marine life. Another water parameter such as bacteria (Total Coliform bacteria, Streptococci Bacteria) that were utilized as a direct result of untreated sewage disposal in sea water, Bacterial pathogens ( coli form organism) in sea water will make a serious contagious for all kinds of aquatic life and expose them to viruses infection such as gastro-enteritis and infectious hepatitis. These viruses cause variety of symptoms such as rashes, fever, gastroenteritis, meningitis, respiratory system disease, and hepatitis .Viruses symptoms such as viral gastroenteritis, usually of with nausea, vomiting and diarrhea, take place in people who will be fed by such infected sea foods. In order to overcome hepatitis rest and restricted activities will be needed for a period of time, In other hand severe cases of hepatitis may cause death at the end as a result of liver failure,[2].The existing of Phosphorus (po4-p) in sea water will increase the aquatic plants growth ability which will lead to population increasing of aquatic organisms as a result of that. The increasing of both COD (chemical oxygen demand) and BOD (Biochemical oxygen demand)will reduce the dissolved oxygen in water that is needed for aquatic organism life.

\section{Egypt Law no.4 for (1994) for the marine environment:}

According to the Egyptian government environmental law No. 48 of 1982 [3] that is concerning the Protection of the Egypt water resources such Nile river, ground water and sea water the discharge of any substances shall not exceed the levels indicated values in table(1). There is no allowance of discharging any substances into the marine environment except at a minimum distance of 500 meters from the shoreline in order to mitigate the negative effects from fishing zones, bathing zones or nature reserves. 
Table 1. Water Limit values for Law no.4 for Egypt (1994) compared to (WHO) water quality guideline values[3]

\begin{tabular}{|c|c|}
\hline Pollutant Item & Maximum limits (mg/Liter-unless otherwise indicated.) \\
\hline Temperature & Not to exceed 10 degrees over the prevailing rate. \\
\hline PH & $6-9$ \\
\hline Colour & Free of coloring materials \\
\hline Biochemical Oxygen Demand ( BOD) & 60 \\
\hline Chemical Oxgyen Demand (COD) & 100 \\
\hline Total Dissolved Solids & 2000 \\
\hline Volatile Solids & 1800 \\
\hline Suspended materials & 60 \\
\hline Turbidity & NTU 50 \\
\hline Sulphides & 1 \\
\hline Oil and Greases & 15 \\
\hline Hydrocarbons of oil origin & 0.5 \\
\hline Phosphates & 5 \\
\hline Nitrates & 40 \\
\hline Phenolates & 1 \\
\hline Fluoride & 1 \\
\hline Aluminium & 3 \\
\hline Ammonia (nitrogen) & 3 \\
\hline Arsenic & 0.05 \\
\hline Chromium & 1 \\
\hline Copper & 1.5 \\
\hline Nickel & 0.1 \\
\hline Iron & 1.5 \\
\hline Manganese & 1 \\
\hline Zine & 5 \\
\hline Silver & 0.1 \\
\hline Barium & 2 \\
\hline Cobalt & 2 \\
\hline Pesticides & 0.2 \\
\hline Cyanide & 0.1 \\
\hline stimated Fecal Coliform Count in $100 \mathrm{~cm} 3$ & 5000 \\
\hline
\end{tabular}

\section{Damietta harbor description}

Damietta port is located $10 \mathrm{Km}$ to the west of the Nile River ( Damietta Branch )and $70 \mathrm{Km}$ to the west of port said and $200 \mathrm{Km}$ from Alex Port. ), The port is connected with the many of main transport network of Egypt such as road network, railway network and also river navigational network. The harbor has access Channel is about $11.3 \mathrm{~km}$ long , $300 \mathrm{~m}$ wide and $15 \mathrm{~m}$ depth also the river Nile is connected to the port via barge channel of $4.5 \mathrm{~km}$ long, $5 \mathrm{~m}$ deep and $90 \mathrm{~m}$ width as shown in fig (2). The harbor Total area is almost 11.8 milion $\mathrm{m}^{2}$ that divided to land area about 7.9 million $\mathrm{m}^{2}$ will be increased in the future to 8.6 million $\mathrm{m}^{2}$ and water area about 3.9 million $\mathrm{m}^{2}$.Percentage of harbor water to harbor land area is $1: 3$ as shown in fig (3)[ 4].
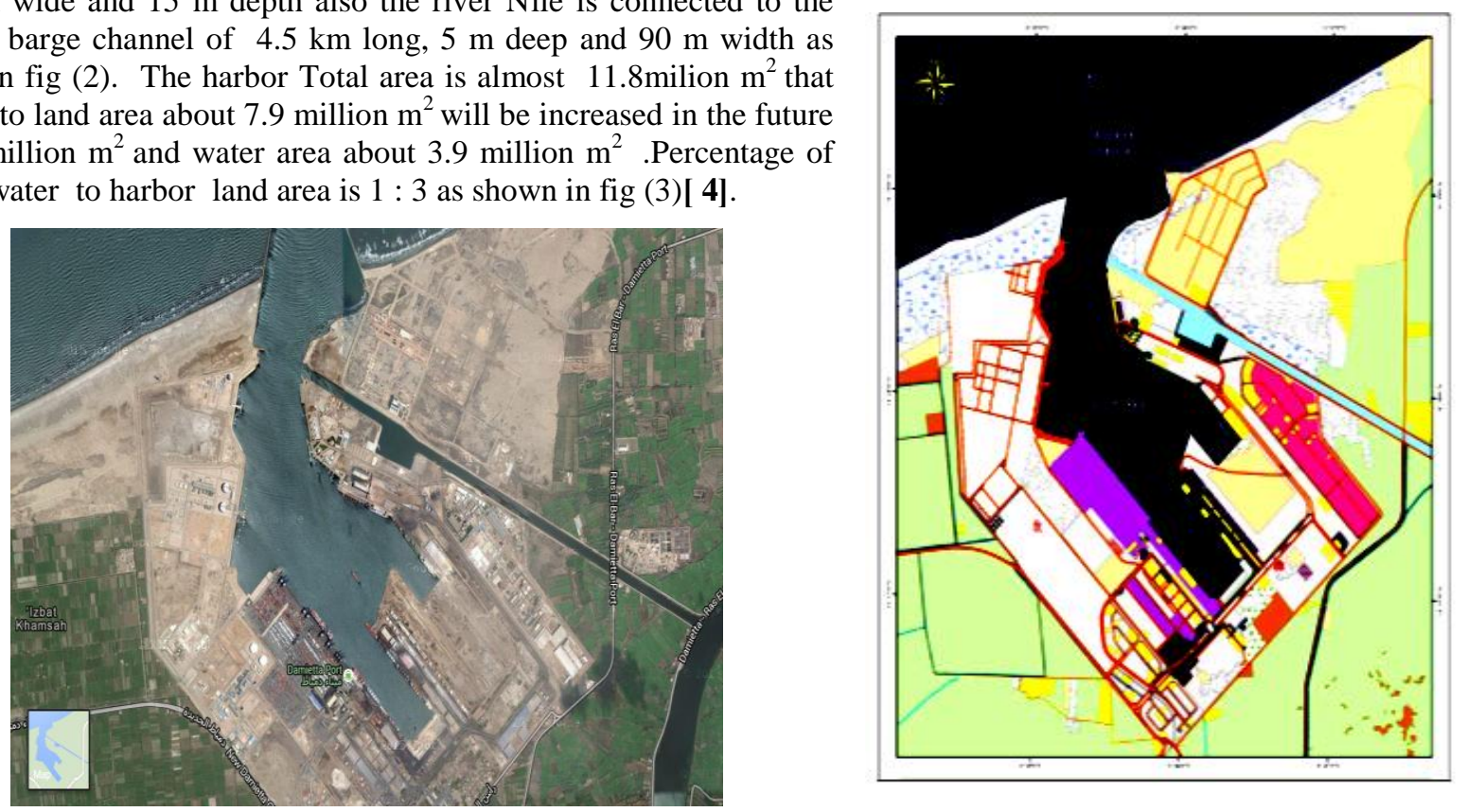
Port Traffic for example during 1/1/2011 to 30/6/2012, Ships and cargo traffic in Damietta port From 1/7/2010 To $1 / 7 / 2012$ can be shown from table (2) to table (3) and from fig (4) to fig (5) [5]. Containers Handling in Damietta Port During Period From 1/7/2011 To 30/6/2012Compared to The Corresponding Period of The Last Year can be shown from table (2).

Table (2) Containers Handling in Damietta Port During Period From 1/7/2011 To 30/6/2012[5]

\begin{tabular}{|c|c|c|c|c|c|c|c|c|c|}
\hline & \multirow{3}{*}{ Unit } & \multicolumn{6}{|c|}{ : Containers Handling Duraing } & \multirow{3}{*}{$-/+$} & \multirow{3}{*}{$\%$} \\
\hline & & \multicolumn{3}{|c|}{$1 / 7 / 2011$ to $30 / 6 / 2012$} & \multicolumn{3}{|c|}{$1 / 7 / 2010$ to $30 / 6 / 2011$} & & \\
\hline & & Import & Export & Total & Import & Export & Total & & \\
\hline Local Containers & \multirow{3}{*}{ TEU } & 97940 & 130507 & 228447 & 80594 & 122364 & 202958 & 25489 & $\% 12.5$ \\
\hline Transit Containers & & 317920 & 292219 & 610139 & 379796 & 353480 & 733276 & \begin{tabular}{c|}
- \\
123137 \\
\end{tabular} & $\begin{array}{c}- \\
\% 16.7 \\
\end{array}$ \\
\hline Total & & 415860 & 422726 & 838586 & 460390 & 475844 & 936234 & $97648-$ & $\begin{array}{c}- \\
\% 10.4\end{array}$ \\
\hline & & & & & & & & & \\
\hline
\end{tabular}

Cargo Handling in Damietta Port During Period From 1/7/2010 To 1/7/2012 Compared to The Corresponding Period of The Last Year can be shown from table (3) [5].

Table (3) Cargo Handling in Damietta Port During Period From 1/7/2011 To 30/6/2012[5]

\begin{tabular}{|c|c|c|c|c|}
\hline \multirow{2}{*}{ Vessels } & \multicolumn{2}{|c|}{ : Vessel Traffic During Period } & \multirow{2}{*}{$-/+$} & \multirow{2}{*}{$\%$} \\
\hline & $1 / 7 / 2011$ to $30 / 6 / 2012$ & $1 / 7 / 2010$ to $30 / 6 / 2011$ & & \\
\hline G.Cargo & 587 & 698 & $111-$ & $\% 15.9-$ \\
\hline Drv Bulk & 553 & 715 & $162-$ & $022.6-$ \\
\hline Liquid Bulk & 223 & 189 & 34 & $\% 17.9$ \\
\hline Liquified Gas & 45 & 65 & $20-$ & $\% 30.7-$ \\
\hline Total No. of G.Cargo Vessels & 1408 & 1667 & $259-$ & $\% 15.5-$ \\
\hline Total No. of Containers Vessels & 1111 & 1292 & $181-$ & $\% 14-$ \\
\hline Total No. of Vessels & 2519 & 2959 & $440-$ & $\% 14.8-$ \\
\hline
\end{tabular}

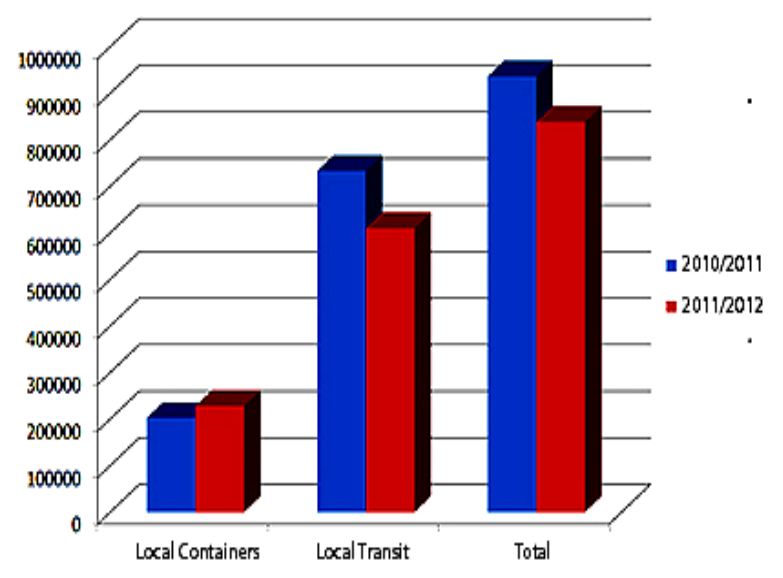

FIG(4) Containers Handling in Damietta Port During Period From 1/7/2011 To 30/6/2012 


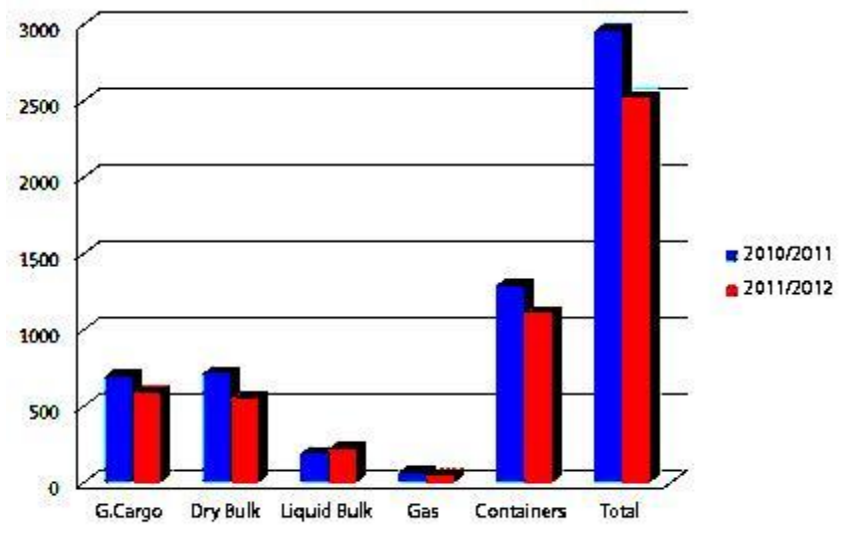

FIG(5) Cargo Handling in Damietta Port During Period From 1/7/2011 To 30/6/2012

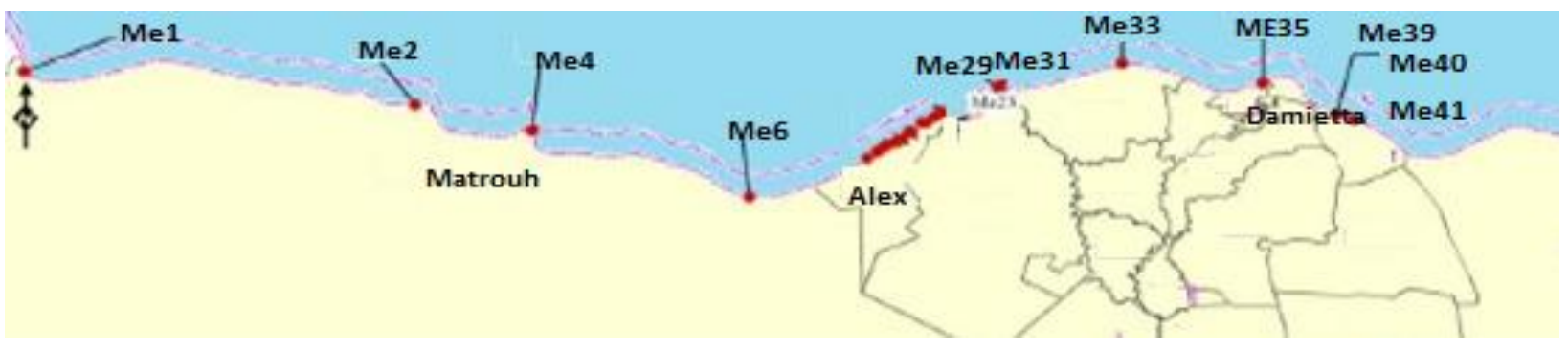

FIG(6) Egypt north coast different monitoring locations

\section{Egypt environmental authorities Mediterranean campaign :}

The Egyptian government sent Mediterranean campaigns environmental since 1994 to collect water samples to analyze it in order to monitor its quality, these samples were taken from many different recording points along Egypt north coast as shown in fig (6).

The data included many sea water parameters such as water dissolved oxygen (DO), a total Coliform bacteria, Streptococci Bacteria and a total suspended solids was recorded as shown in fig (7), (8), (9) and (10) respectively for July (2014) campaign as a example[1].

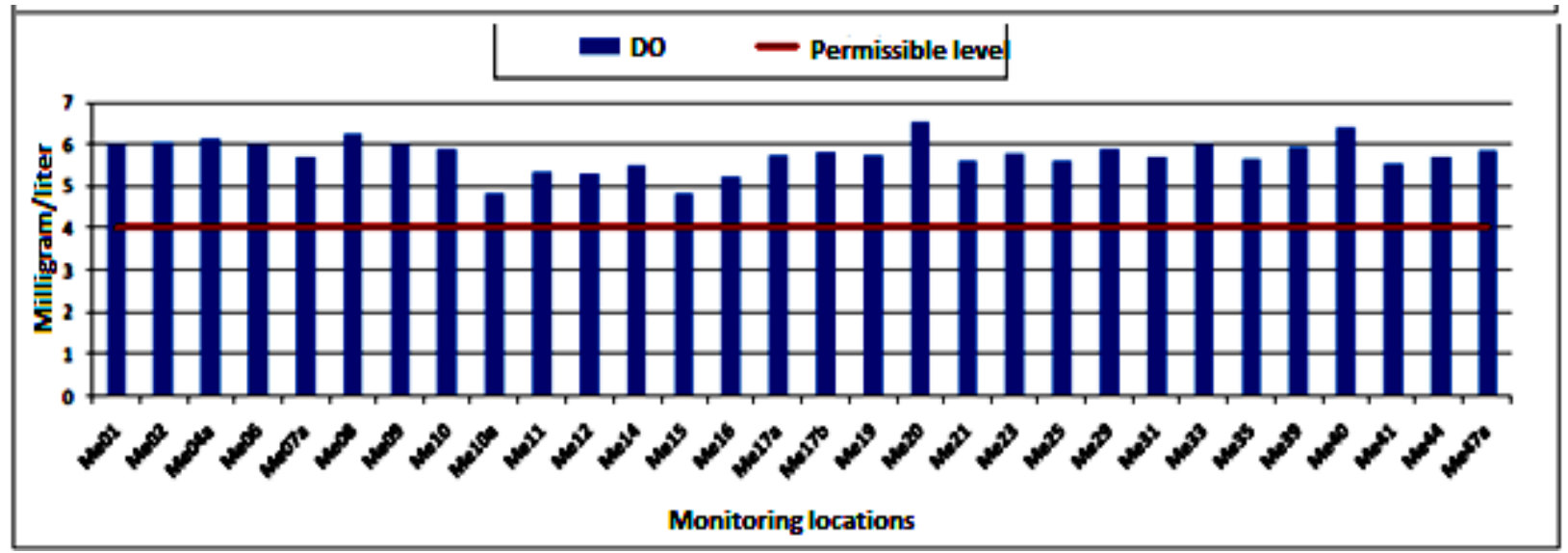

FIG(7) Water dissolved Oxygen 


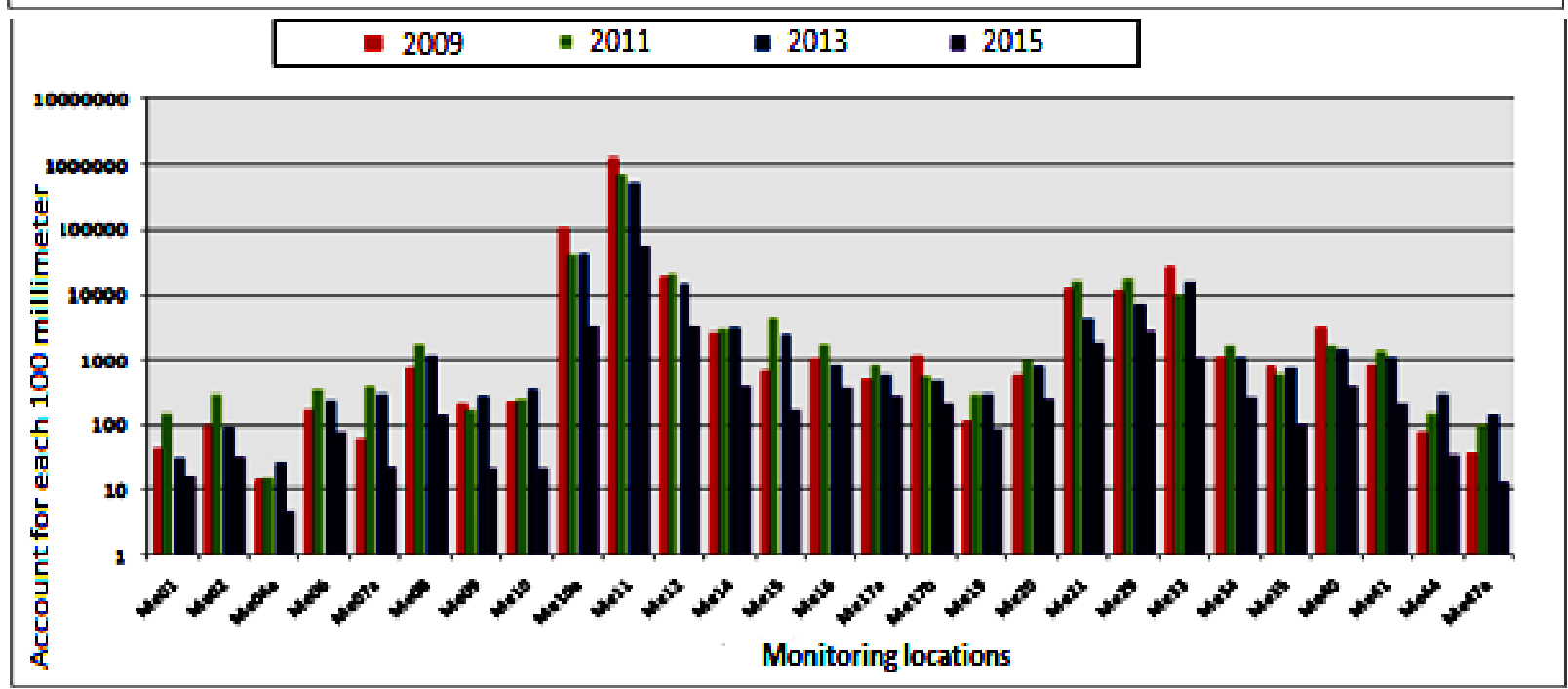

FIG(8) Total Coliform bacteria

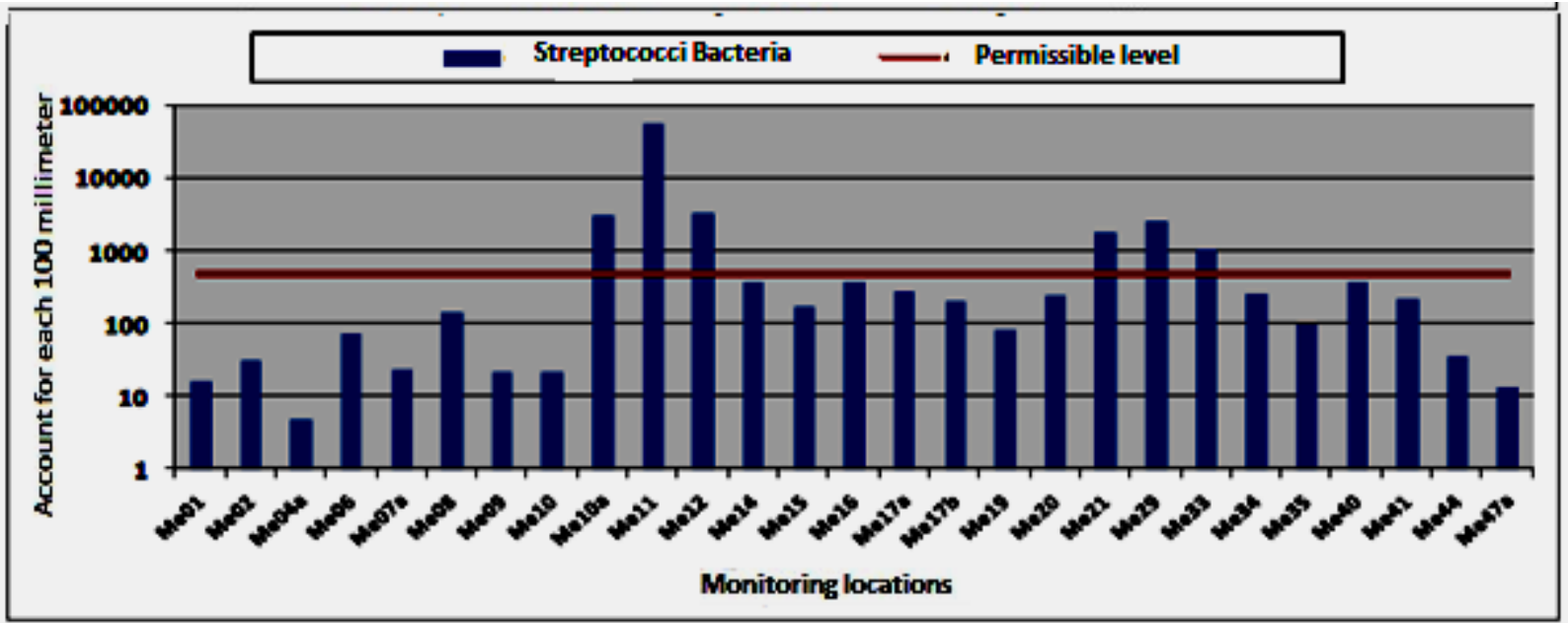

FIG(9) Streptococci Bacteria

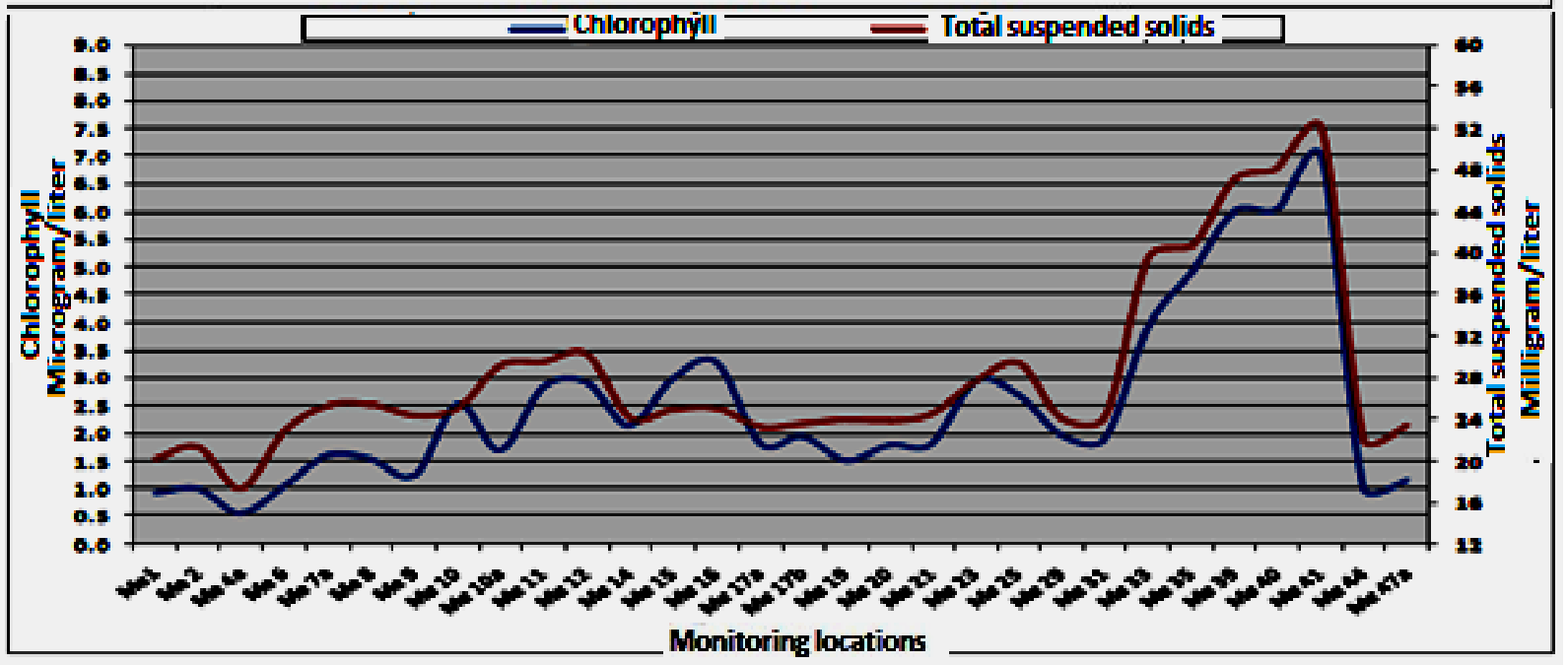

FIG(10) Water chlorophyll 


\section{Results}

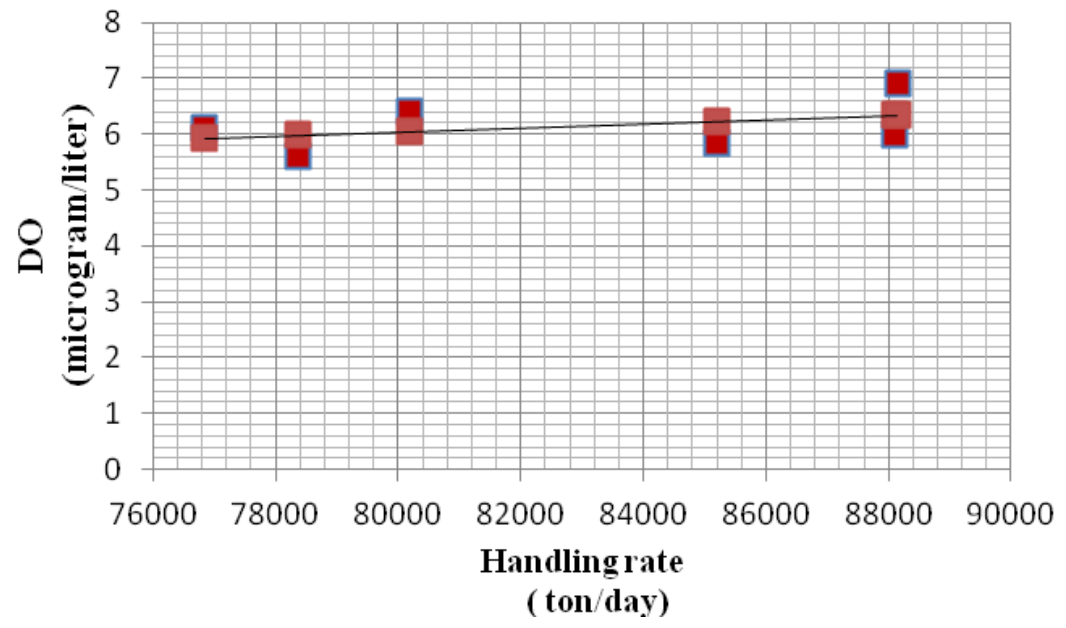

FIG(11) Containers Handling in Damietta Port versus DO

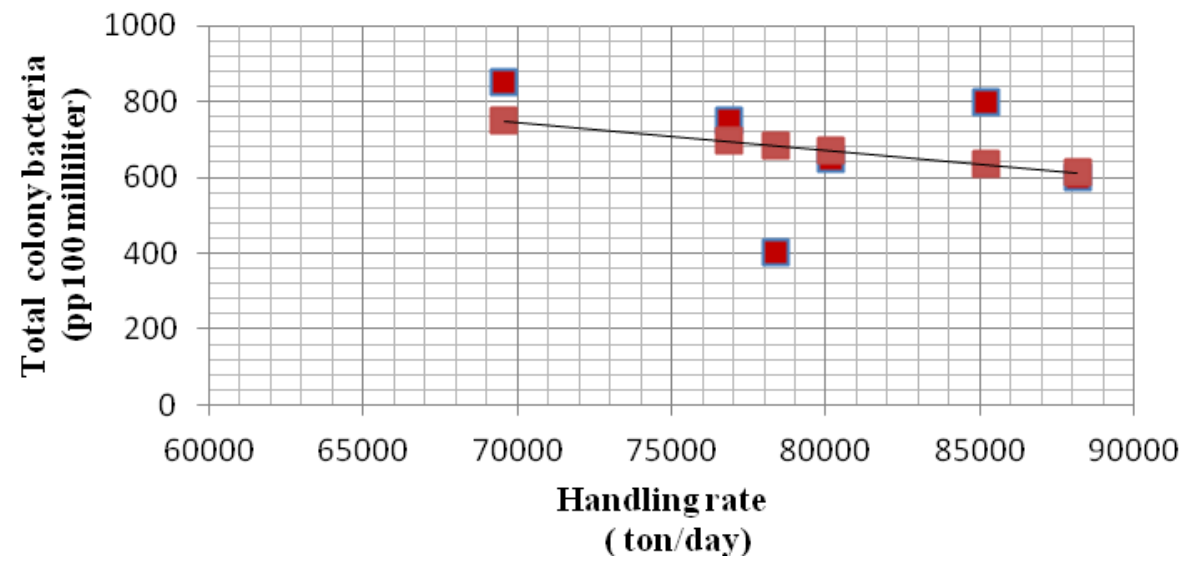

FIG(12) Containers Handling in Damietta Port versus total colony bacteria

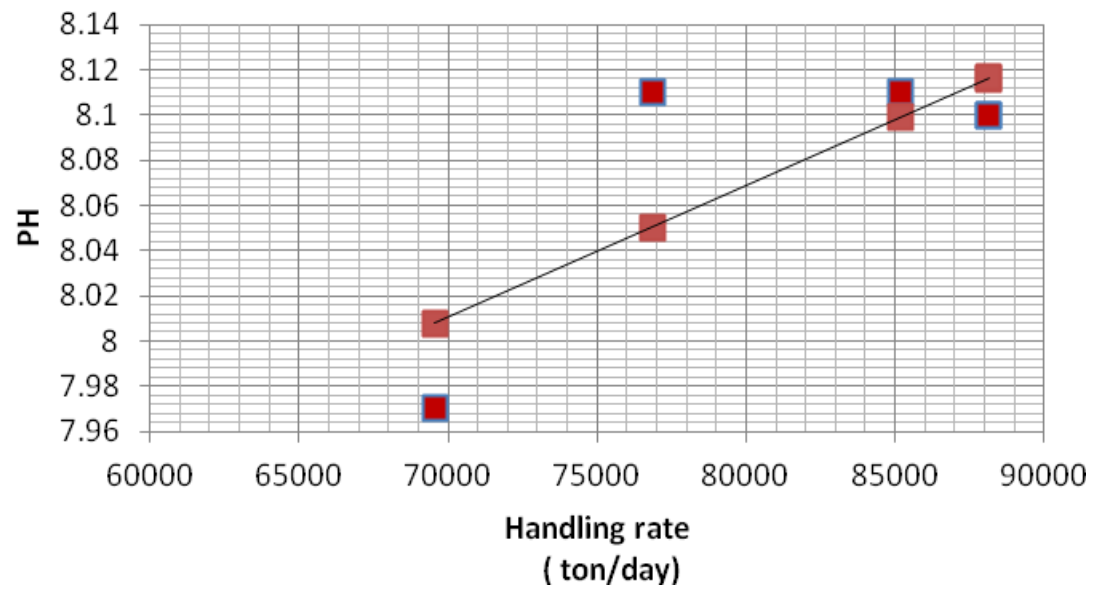

FIG(13) Containers Handling in Damietta Port versus PH 
THE RELATION BETWEEN CARGO OPERATION AND WATER POLLUTION IN DAMIETTA HARBOR

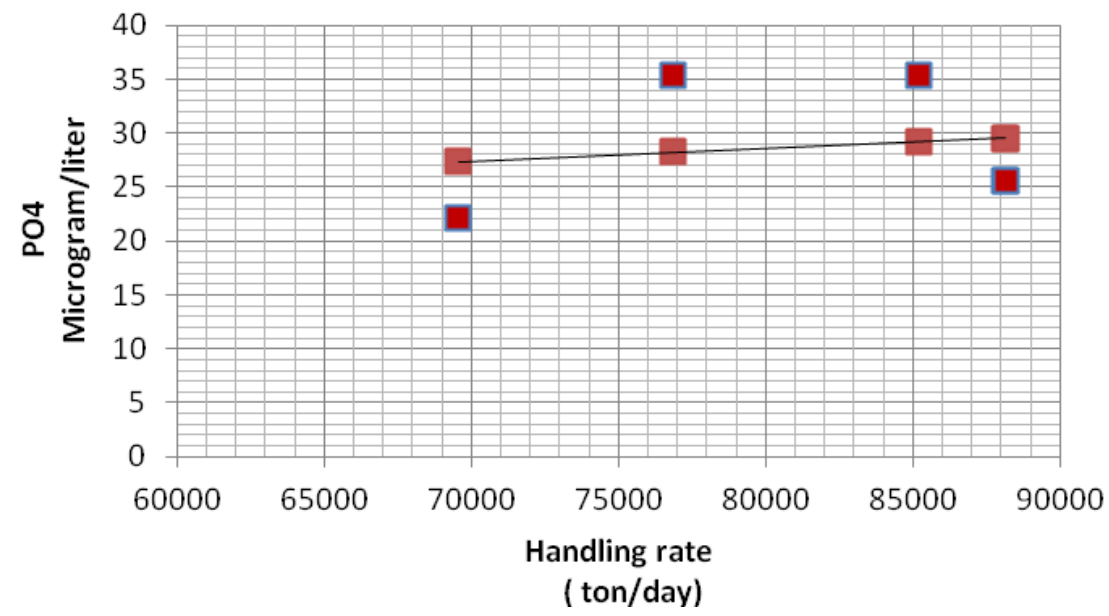

FIG(14) Containers Handling in Damietta Port versus PO4

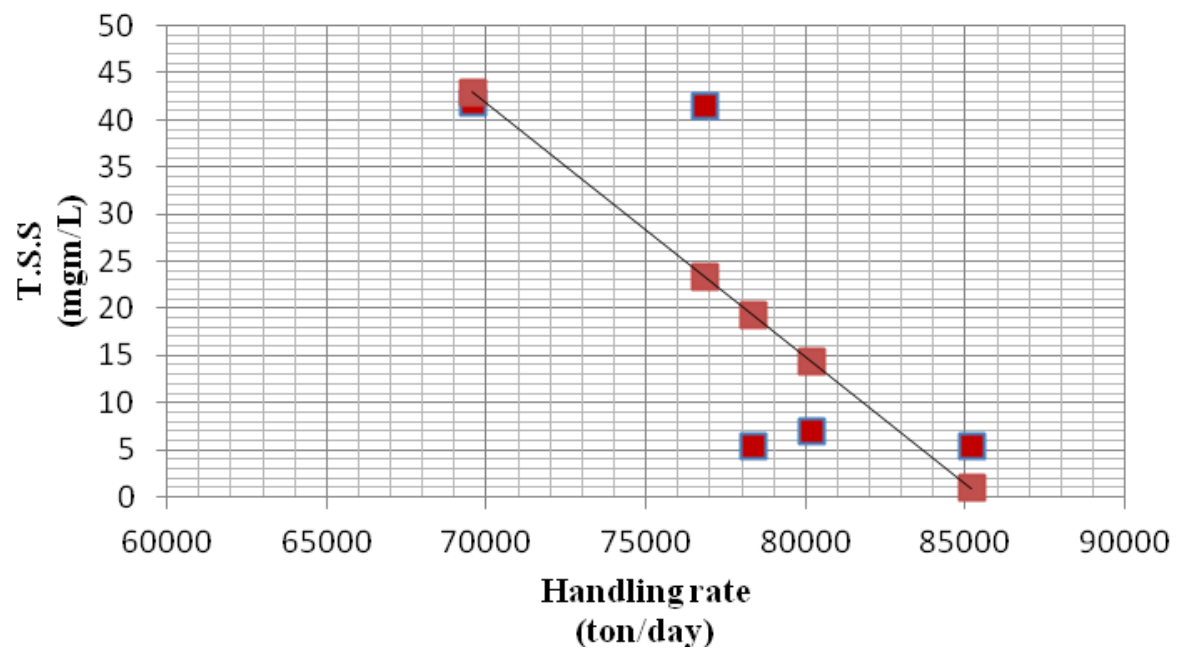

FIG(15) Containers Handling in Damietta Port versus T.S.S

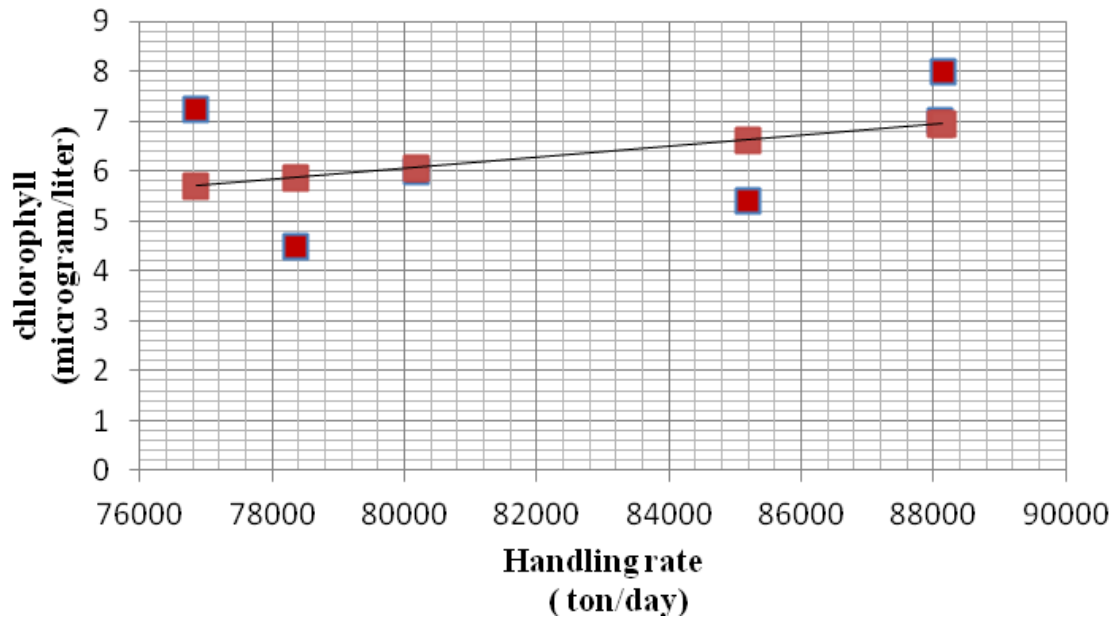


FIG(16) Containers Handling in Damietta Port versus c chlorophyll

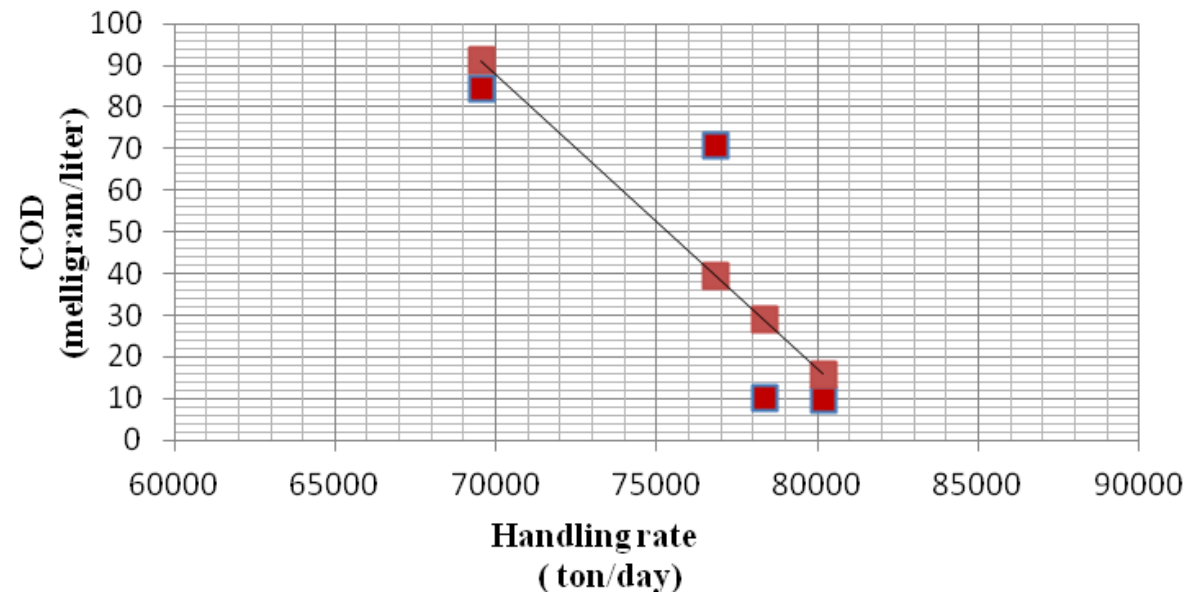

FIG(17) Containers Handling in Damietta Port versus COD

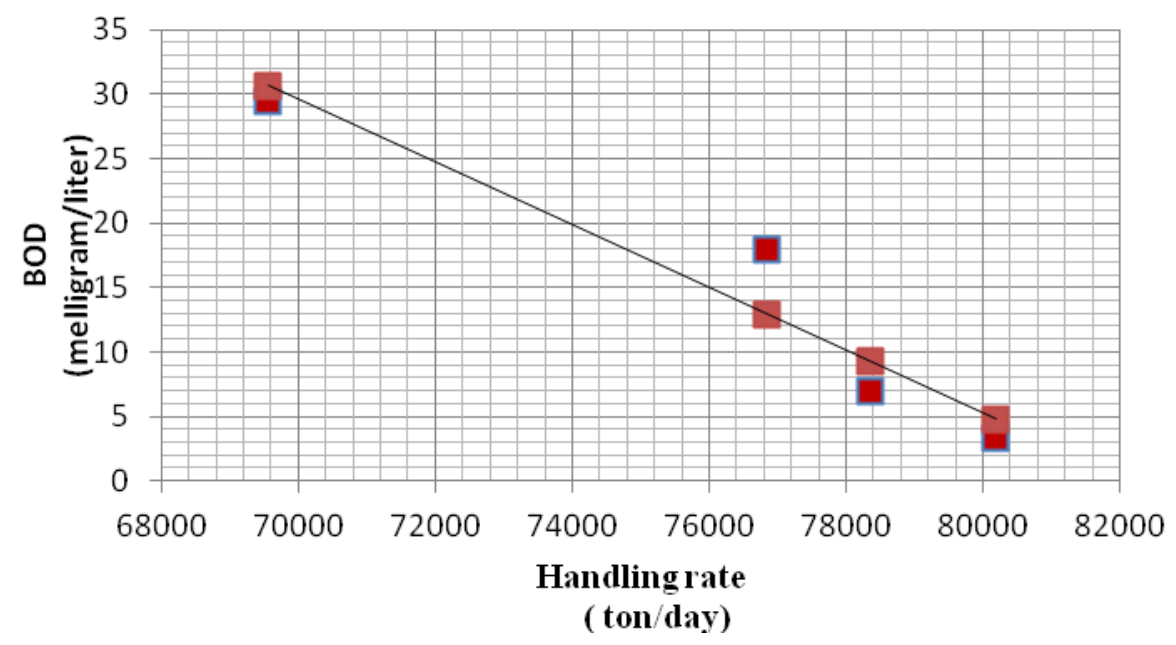

FIG(18) Containers Handling in Damietta versus BOD

\section{Result analysis}

- We can see from fig (11) that the rate of handling for Damietta harbor is increasing with the increasing of DO due, The dissolved oxygen was within the acceptable marginal which caused fish population to be increased as other aquatic species and will contribute to the food supply for coastal urban area, fish meat is protein source for human muscles building.

- As shown from fig (12) the rate of handling for Damietta harbor is decreasing with the increasing of Total Colony bacteria due the fact that sea foods is infected with viruses, viruses are capable of producing a wide variety of syndromes, including rashes, fever, gastroenteritis, meningitis, respiratory disease which eventually effect on labor health.

- As shown from fig (13) the rate of handling for Damietta harbor is increasing with the increasing of water PH due the reason that the PH level was within 7 to 8 , The young and adult fish species can survive in such environment, most fish eggs can hatch and that will provide a good food supply for the nearest community.

- As shown from fig (14) the rate of handling for Damietta harbor is increasing with the increasing of Phosphate phosphorus $\left(\mathrm{PO}_{4}-\mathrm{P}\right)$ due the reason that Phosphorus (po4-p) in sea water will increase the growth rate of phytoplankton and aquatic plants which is major food supply or aquatic organisms, Also aquatic organisms population will be increased as a result of that. 
- As shown from fig (15) the rate of handling for Damietta harbor is increasing with the increasing of chlorophyll, The chlorophyll is used by photosynthetic plankton, or phytoplankton, present in the ocean which impact fish and other marine life and can affect economic productivity and food availability.

- As shown from fig (16) the handling rate for Damietta harbor is decreasing with the increasing of total suspended solids due the reason that suspended solids( organic and non-organic particles) in sea water cause water turbidity and resist sun ray penetration in water, When sun ray in sea water is decreased aquatic plants photosynthesis will be decreased and that will lead to its death which will affect on fish food sources. Also suspended solids in water absorb more heat which will cause water temperature to be increased and DO will be decreased as a result of that, Pathogens and toxic metals can be attached to total suspended solids and cause unhealthy environment for aquatic marine organism and that will be reflected on human health by negative impact after period of time which will reverse the relation between handling rate and total suspended solids.

- As shown from fig (17) to fig (18) the rate of handling for Damietta harbor is decreasing with the increasing of both COD and BOD because both of them reduce the dissolved oxygen in water which is needed for aquatic organism life also it will reduce its population.

\section{Comparison between Damietta harbor and top ranked harbors}

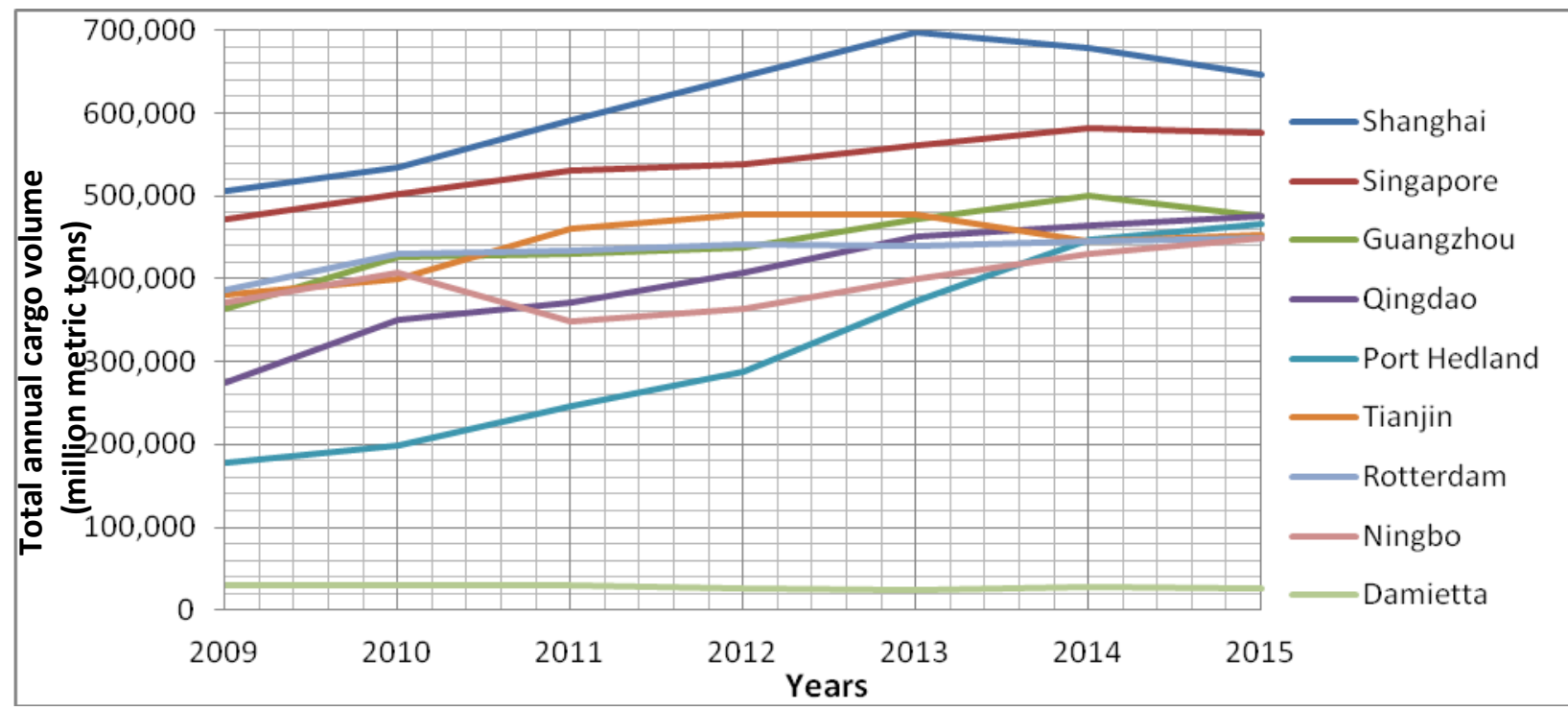

FIG(19) Annual Containers Handling in top ranked Ports During Period From 2009 to 2015[6]

Fig (19) represents the annual containers handling for Damietta harbor and different top ranked harbors( Shanghai harbor, Singapore harbor, Guangzhou harbor, Qingdao harbor, Port Hedland harbor, Tianjin harbor, Rotterdam harbor and Ningbo harbor) from year 2009 to year 2015[6]. Regarding to Hedland port as shown in fig (20) we found that it jumped from Total annual cargo volume 178,625 million metric tons at year 2009 to 466,363 million metric tons at year 2015 and that due to fact that the harbor is located in the north-west of Australia where the coastal environment is being largely good, This progress situation was taken place because the Australian authorities regulated marine damping and the in land sewage effluent to the ocean in order to maintain the marine aquatic life within the permissible limits [7]. Shanghai port as shown in fig (21) kept its rank at the top from 2009 to 2015 because the Chinese authorities prevented and controlled of marine environment pollution caused by collection of ships pollutants operations such as garbage and oil spots. 


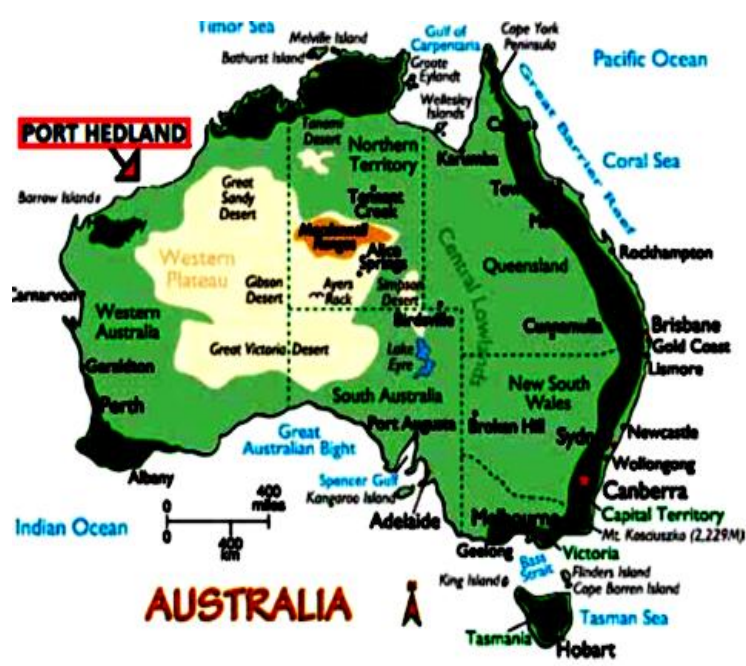

FIG(20) Hedland port

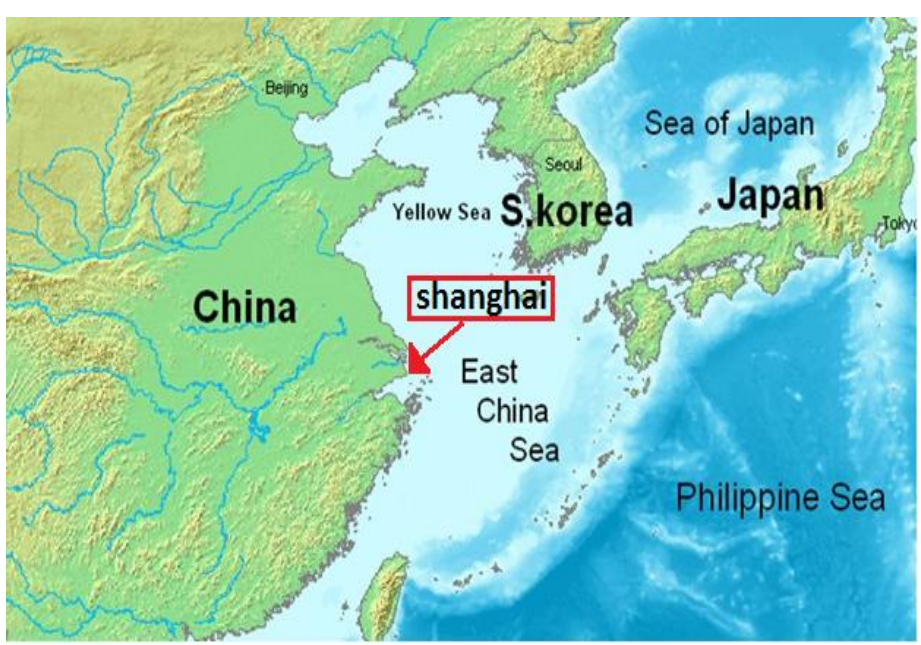

FIG(21) Shanghai port

In the previous figure we can found that the Damietta harbor annual cargo is decreasing along the years compared to other harbors and that may be due to different reasons such economic stress, political conflict and air and water pollution. Damietta branch suffer from pollution that was resulted from factories effluent, electric station cooling water and near urban area untreated sewage, Also irrigation drains get rid of its water to the Damietta branch without any treatment especially drain no 6 from Damietta to new Damietta This pollutants find its way into the sea through the river branch mouth and that will cause the severe infection of the aqua marine life beside the current pollution that take place at harbor marine water as result of ships operations. Water pollution is affecting on food chain to the way that it will be reflected on people health of the surrounding labors community to cause physical attitude damping in cargo handling processes, To avoid such thing we need to increase government efforts to control water pollution by powerful legalizations in order to minimize direct and indirect pollution sources, Also we need construct a monitor system to maintain the water parameters within the permissible limits.

\section{Proposed monitoring system}

The proposed monitoring system inside Damietta port processes is shown in fig (22) and it must include a many rules as follow:

1- Prohibit the transfer of pollutants from ships while the vessel is within the port water area without the port authority approval.

2- Prohibit the ship tank cleaning operations as well as collection and disposal of residue oil, oily water, water that contains toxic and harmful substances, garbage, sewage and exhaust gas ("Regulated Operations").

3- On each ship board there is must be record book include all the ships operations and this book will be investigated by the port authority to check if there is any violation.

4- Strong action include high financial penalty must be taken against any ship violation.

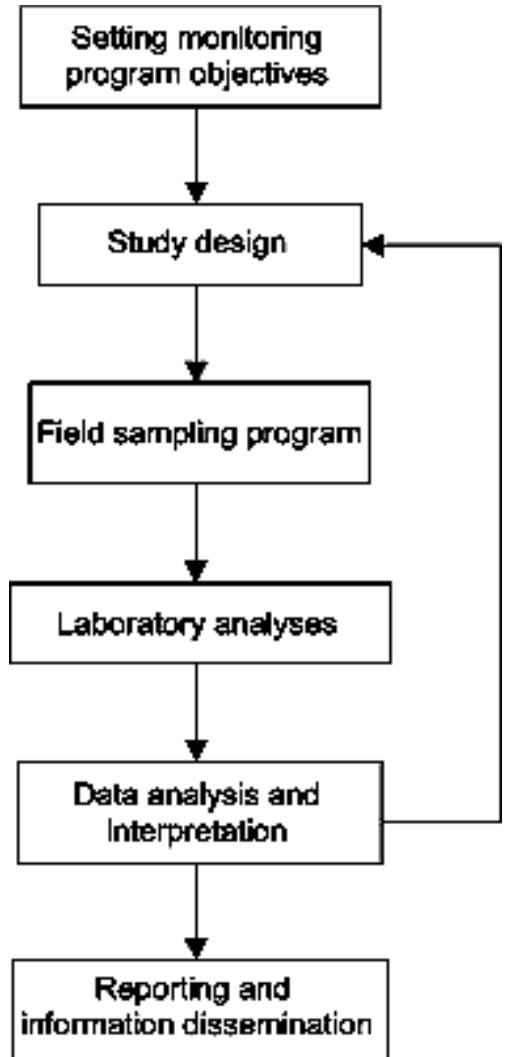


5- Activate the environmental Law no.4 for Egypt (1994) to control surrounding urban and industrial area emissions which contribute in ports water pollution.

6- Preventing any sea damping for untreated effluent sewage from any surrounding urban areas.

7- Collect water sample from Damietta branch mouth to detect any water quality changes and if that was the case a quick solution must be carried out.

8- Water samples from Damietta port water area must be taken to detect any water quality changes.

FIG(22) Monitoring program processes[7]

\section{CONCLUSIONS}

It was noticed that in Damietta port the following facts:

1- The daily handling rate is increasing with the dissolved oxygen (DO) in sea water and that because the dissolved oxygen cause fish population to be increased which is a protein source for human muscles building.

2- Daily handling rate is decreased with the increasing of both Total Colony bacteria because that sea foods is infected with viruses which effect by negative impact on labor health.

3- Daily handling rate is increasing with the increasing of water $\mathrm{PH}$ due the reason that the $\mathrm{PH}$ level was within 7 to 8 , The young and adult fish species can survive in such environment, most fish eggs can hatch and that will provide a good food supply for the nearest community.

4- Daily handling rate is increasing with the increasing of Phosphate phosphorus $\left(\mathrm{PO}_{4}-\mathrm{P}\right)$ due the reason that Phosphorus (po4-p) in sea water will increase the growth rate of phytoplankton and aquatic plants which is major food supply or aquatic organisms

5- Daily handling rate is increasing with the increasing of chlorophyll, The chlorophyll is used by photosynthetic plankton, or phytoplankton, present in the ocean which impact fish and other marine life and can affect economic productivity and food availability.

6- Daily handling rate is decreasing with the increasing of total suspended solids due the reason that it cause water turbidity, Also it resist sun ray penetration in water that decrease aquatic plants photosynthesis and lead to its death which will affect on fish food sources. Also suspended solids in water absorb more heat which will cause water temperature to be increased and DO will be decreased as a result of that, Pathogens and toxic metals can be attached to total suspended solids and cause unhealthy environment for aquatic marine organism and that will be reflected on human health by negative impact.

7- Daily handling rate is decreased with the increasing of both COD and BOD because both of them reduce the dissolved oxygen in water which is needed for aquatic organism life.

\section{Recommendations}

1-Control and preventing all pollution sources inside marine water and treat all the land inflow sewage before sea damping processes.

2-A study of waste disposal in sea effect on cargo handling operation inside Borsaid and Suez ports.

3- A study of water salinity effect on cargo handling operation inside Damietta port, Alex port, Borsaid port and Suez port .

4- Establishing a well-organized monitoring system in order to watch the water quality inside Damietta port marine water to detect any water quality changes and to give recommendations to avoid such problem.

5-Establishing especial legislations and rules for ports to give more control of ship fuel leakage. 6-Activate the environmental Law no.4 for Egypt (1994) to control surrounding urban and industrial area emissions which contribute in ports water pollution.

\section{REFERENCES}


[1] EEAA, Egyptian environmental affairs Mediterranean water Quality campaign Reports, (2009) to (2015).

[2] FAQ, Fishery Harbor Manual on the Prevention of Pollution, Chapter (1) Potential pollutants, their sources and their impacts, http://www.fao.org/docrep/X5624E/x5624e04.htm..

[3] Law number 4 of 1994, promulgating the environmental law presidential decree, EGYPT (1994).

[4]Damietta Port Authority website-www.apa.gov.eg .

[5]Damietta Port Authority - General Department of Information Center report-operation status reports (2009) to (2015).

[6] http://www.worldshipping.org/about-the-industry/global-trade/top-50-world-container-ports

[7] Australian guidelines for water quality monitoring and reporting, October 2000. 